\title{
LIMITS TO THE SALIENCE OF ULTRAVIOLET: LESSONS FROM COLOUR VISION IN BEES AND BIRDS
}

\author{
PETER G. KEVAN ${ }^{1}$, LARS CHITTKA ${ }^{2}$ AND ADRIAN G. DYER ${ }^{3, *}$ \\ ${ }^{1}$ Department of Environmental Biology and Department of Botany, University of Guelph, Guelph, ON, \\ Canada N1G 2W1, ${ }^{2}$ Biozentrum, Zoologie II, Am Hubland, Universität Würzburg, 97074 Würzburg, Germany \\ and ${ }^{3}$ Faculty of Science, Monash University, Victoria 3800, Australia \\ *Author for correspondence (e-mail: adrian.dyer@sci.monash.edu.au)
}

Accepted 19 April 2001

\begin{abstract}
Summary
Ultraviolet is an important component of the photic environment. It is used by a wide variety of animals and plants in mutualistic communication, especially in insect and flower inter-relationships. Ultraviolet reflections and sensitivity are also becoming well considered in the relationships between vertebrates and their environment. The relative importance of ultraviolet vis $\grave{a}$ vis other primary colours in trichromatic or tetrachromatic colour spaces is discussed, and it is concluded that ultraviolet is, in most cases, no more important that blue, green or red reflections. Some animals may use specific wavebands of light for specific reactions, such as ultraviolet in escape or in the detection of polarised light, and other wavebands in stimulating feeding, oviposition or mating. When colour

knowledge of the neuronal wiring used to evaluate the signals from all receptor types, including the ultraviolet. Evolutionary analyses suggest that, at least in arthropods, ultraviolet sensitivity is phylogenetically ancient and undergoes comparatively little evolutionary fine-tuning. Increasing amounts of ultraviolet in the photic environment, as caused by the decline of ozone in the atmosphere, are not likely to affect colour vision. However, a case for which ultraviolet is possibly unique is in the colour constancy of bees. Theoretical models predict that bees will perform poorly at identifying pure ultraviolet signals under conditions of changing illumination, which may explain the near absence of pure ultraviolet-reflecting flowers in nature.
\end{abstract} vision and, thus, the input from more than a single spectral receptor type are concerned, we point out that even basic predictions of signal conspicuousness require

Key words: colour constancy, evolution, flower colour, illumination, insect.

\section{Introduction}

Ultraviolet reflections from flowers have been recorded for over a century (Knuth, 1891a; Knuth, 1891b), and have been related to ultraviolet sensitivity in insect vision since (Kühn, 1924; Kühn, 1927). More recently, ultraviolet vision has been studied in vertebrates (Goldsmith, 1980; Bowmaker, 1980; Neumeyer, 1985; Jacobs, 1992; Tovée, 1995; although Wolff, 1925, had demonstrated ultraviolet sensitivity in minnows much earlier) and related to objects of interest in their environments (Burkhardt, 1982; Bennett and Cuthill, 1994; Bennett et al., 1996; Bennett et al., 2001). Many insects and vertebrates have been shown to have multiple classes of photoreceptors that contribute to colour vision, for example, the honeybee has trichromatic vision based on ultraviolet, blue and green photoreceptors (Peitsch et al., 1992). Tetrachromacy based on ultraviolet, blue, green and red photoreceptors is also well represented throughout the animal kingdom (see Backhaus et al., 1998). Despite the acknowledged fact that colour vision requires the integration of information from all the primary receptors, ultraviolet has often been singled out for special consideration.

Numerous botanical studies have examined the ultraviolet reflections from flowers without reference to the colour perception of the flower's visitors (see references in Kevan and Backhaus, 1998). Studies of ultraviolet patterns from flowers may have some value for taxonomic purposes. For ecological and ethological analyses, however, this approach is erroneous (Kevan, 1972; Kevan, 1978; Kevan, 1979a; Kevan, 1983; Kevan and Backhaus, 1998; Chittka, 1992; Chittka and Menzel, 1992; Chittka et al., 1994; Menzel and Shmida, 1993). It seems that some vertebrate biologists have also fallen into similarly inappropriately constrained approaches by recording ultraviolet reflections from objects without considering the rest of their subjects' colour vision. Investigation of the ultraviolet channel of a visual system alone can only provide limited information about the reflectance spectra of a stimulus, as this type of data does not consider the multiple photoreceptors involved in colour vision (Kevan, 1979a).

Colour measurement requires that the reflectance spectra of a stimulus is measured across the entire wavelength range of an animal's visual system and that those data are plotted in an appropriate colour space. For humans, various colour spaces 


\section{P. G. KEVAN AND OTHERS}

have been proposed, and the science of colorimetry is well developed (Wyszecki and Stiles, 1967). Colour spaces have also been developed for honeybees (Apis mellifera) (e.g. Daumer, 1956; Backhaus, 1991) and trichromatic insects in general (Kevan, 1972; Kevan, 1978; Kevan, 1983; Chittka, 1992; Vorobyev and Brandt, 1997). These colour spaces started with relatively simple Maxwell triangles and have progressed through to colour planes that explain the colour opponency mechanism that appears to operate in many species of bees (Backhaus, 1991; Chittka, 1992; Vorobyev and Brandt, 1997). Tetrachromatic colour vision based on four receptor classes, for example, the colour visual systems of goldfish (Carassius auratus) and pigeons (Columba livia), require the construction of a tetrahedron colour space (e.g. Goldsmith, 1990; Neumeyer, 1991; Neumeyer, 1992; Neumeyer, 1998; Vorobyev et al., 1998).

For the trichromatic colour vision of humans the problem of representing colour brightness creates a fourth dimension in colour space, and the possibility exists that tetrachromatic colour vision requires a fifth dimension. Bees lack brightness perception so that the colour space can be accurately represented in two dimensions (Backhaus, 1992). Some animals have been shown to have more than four wavebandspecific optical sensors (Briscoe and Chittka, 2001). For example, some butterflies may have five colour receptors (Arikawa et al., 1987), and stomatopod Crustacea show a remarkable array of ten or more narrow band sensors (Cronin and Marshall, 1989; Cronin et al., 1994). It remains unknown whether all these receptors are somehow interconnected neurally to provide the integration of information that is required for colour vision, or whether some of the individual sensors provide waveband-specific information that is processed neurally outside the paradigms of colour vision.

Vision and colours that include ultraviolet have excited great scientific interest, but is special interest warranted from evolutionary and ecological standpoints? The answer to this appears to be 'no', as ultraviolet-sensitive receptors appear to be extremely common in insects, crustaceans, avians, fishes and reptiles, as well as being present in some mammals and amphibians (Jacobs, 1992; Tovée, 1995). Rather, it appears that vision in the red part of the spectrum is more derived and special (Briscoe and Chittka, 2001).

Ever since the discovery of ultraviolet vision in ants by Sir J. Lubbock (Lord Avebury) in the 19th century (Lubbock, 1881), and in bees a few decades later (Kühn, 1924), it has been assumed by many workers that ultraviolet sensitivity must be an adaptation to a particular lifestyle. This is because, until recently, the only other species whose vision was understood in detail was Homo sapiens, which lacks ultraviolet vision. Comparisons between remotely related taxa (such as bees and humans), however, make little sense in interpreting adaptation (Chittka and Dornhaus, 1999).

\section{Evolution and phylogeny}

Daylight is relatively impoverished in ultraviolet wavelengths (Henderson, 1977), but that was not always the case. The ultraviolet wavelengths in sunlight are attenuated by its passage through the Earth's atmosphere, primarily by $\mathrm{O}_{2}$ and $\mathrm{O}_{3}$. Prior to the major poisoning event by biogenic $\mathrm{O}_{2}$ that started to accelerate in the Silurian and Devonian period (approximately 450 million years ago), solar ultraviolet radiation was presumably more of a major component of daylight (Berkner and Marshall, 1965). At that time, the process of terrestrialization had not yet started, but the progenitors of terrestrial invertebrates and Vertebrata were common inhabitants of shallow seas and their floors, and presumably lived within the highly photic zone of the surficial waters. There, they would be exposed to a much higher incidence of ultraviolet wavelengths than exists today (Berkner and Marshall, 1965; Garrels et al., 1976; Morel, 1974).

To understand why animals have particular sensory capacities, such as ultraviolet sensitivity, we must compare these animals with close relatives that do not share the same lifestyle. For example, to explore whether ultraviolet vision in bees is an adaptation to flower visitation, it is necessary to investigate insects with lineages divergent from those of bees at a time before there were flowers, and from lineages that do not feed from flowers today. Chittka (Chittka, 1996) made such an analysis and found that ultraviolet receptors with maximum sensitivity $\left(\lambda_{\max }\right)$ around $340 \mathrm{~nm}$ are present not only throughout the Pterygota (winged insects) but also in Chelicerata and several Crustacea. Phylogenetic analysis reveals that the Cambrian ancestor of Chelicerata, Crustacea and Insecta probably saw ultraviolet light (Chittka and Briscoe, 2001). In addition, it can be inferred that these ancient arthropods had receptors most sensitive in the green part of the spectrum $\left(\lambda_{\max }\right.$ around $\left.520 \mathrm{~nm}\right)$ and that a blue receptor with a sensitivity around $430 \mathrm{~nm}$ was acquired only later, possibly in Mandibulata, but certainly in Pterygota. Thus, the input

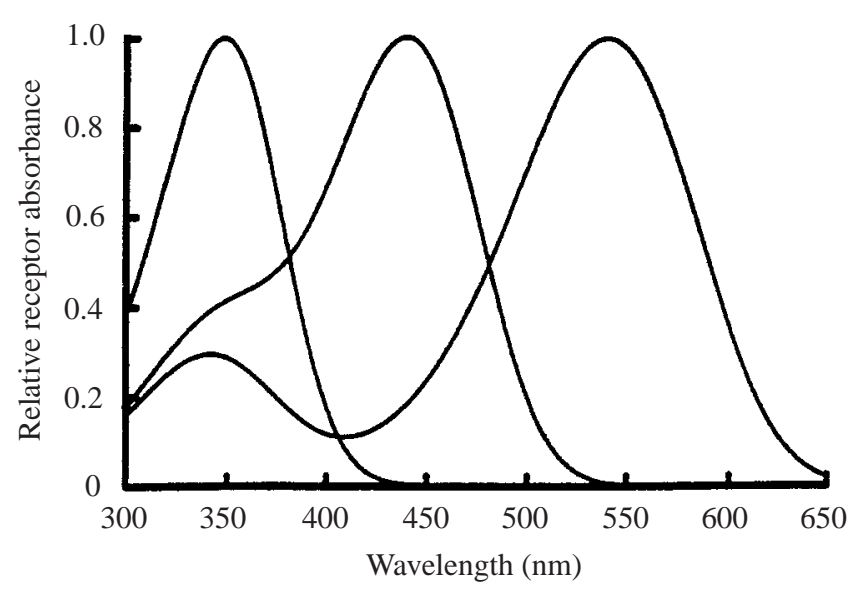

Fig. 1. Spectral sensitivity curves of pigment nomograms (according to Stavenga et al., 1993), calculated for the values of maximum sensitivity of the honeybee's ultraviolet, blue and green receptors (after Peitsch et al., 1992). Curves are normalized to a maximum value of 1.0. Similar curves are shared by many pterygote insects and possibly even the Cambrian ancestor of the mandibulates (Crustacea and Insecta). 
layer of bee color vision with three colour receptor types (see Fig. 1) dates back at least to the Devonian (>360 million years ago).

To confirm the antiquity of spectrally distinct classes of visual pigments, it is useful to establish the molecular phylogeny of the opsins, the protein component of the visual pigments whose amino acid sequence determines spectral sensitivity. To this end, Chittka and Briscoe (Chittka and Briscoe, 2001) evaluated the amino acid sequences of the opsins of several species of arthropods and grouped the most similar sequences using a maximum parsimony approach. Opsins fall into distinct clusters according to spectral sensitivity (Fig. 2). There is one group of ultraviolet-sensitive pigments, a separate group of blue-sensitive pigments, and a third group of longwavelength-sensitive pigments. Crustacean and Chelicerate green-sensitive pigments are more similar to insect green-sensitive pigments than they are to ultraviolet- and blue-sensitive pigments. This suggests that the split between the major classes of opsins (including those sensitive to ultraviolet wavelengths) occurred before the major classes of arthropods separated in the Cambrian. At the neuronal level, Osorio and Bacon (Osorio and Bacon, 1994) suggested that even the basic wiring used to process the input from these spectrally distinct classes of photoreceptors (including ultraviolet) dates back to the ancestor of the Malacostraca (Crustacea) and the Insecta. Generally, the visual information is passed from the receptor level to three successive ganglia, termed the lamina, medulla and lobula, in insects. Of the 8-9 receptor cells in each ommatidium, 6 or 7 terminate in the lamina (short visual fibres), while 1-3 project to the lobula (long visual fibres). On the basis of comparisons between fruitflies, honeybees, locusts and crayfish, Osorio and Bacon (Osorio and Bacon, 1994) concluded that the ancestral Bauplan of these animals involved long-wavelength sensitivity (blue-green) in the short visual fibres, and at least one long visual fibre with ultraviolet sensitivity.

Even though the basic classes of arthropod photoreceptors, with $\lambda_{\text {max }}$ roughly $90 \mathrm{~nm}$ apart, appear well-conserved across arthropods, there remains the possibility of evolutionary fine-tuning. For example, Peitsch et al. (Peitsch et al., 1992) suggested that, within the Hymenoptera, there is a long-wavelength shift in the ultraviolet receptor of forest-dwelling stingless bees. Inspection of the $\lambda_{\max }$ values superimposed on the hymenopteran phylogeny does not reveal strong support for this hypothesis, however. The ultraviolet receptors of all stingless bee species fall well within the scatter of other Apidea (Chittka et al., 2001). Thus, to date, there does not appear to be solid evidence for evolutionary fine-tuning of ultraviolet receptors that could be linked to visual ecology, although such tuning can occur in

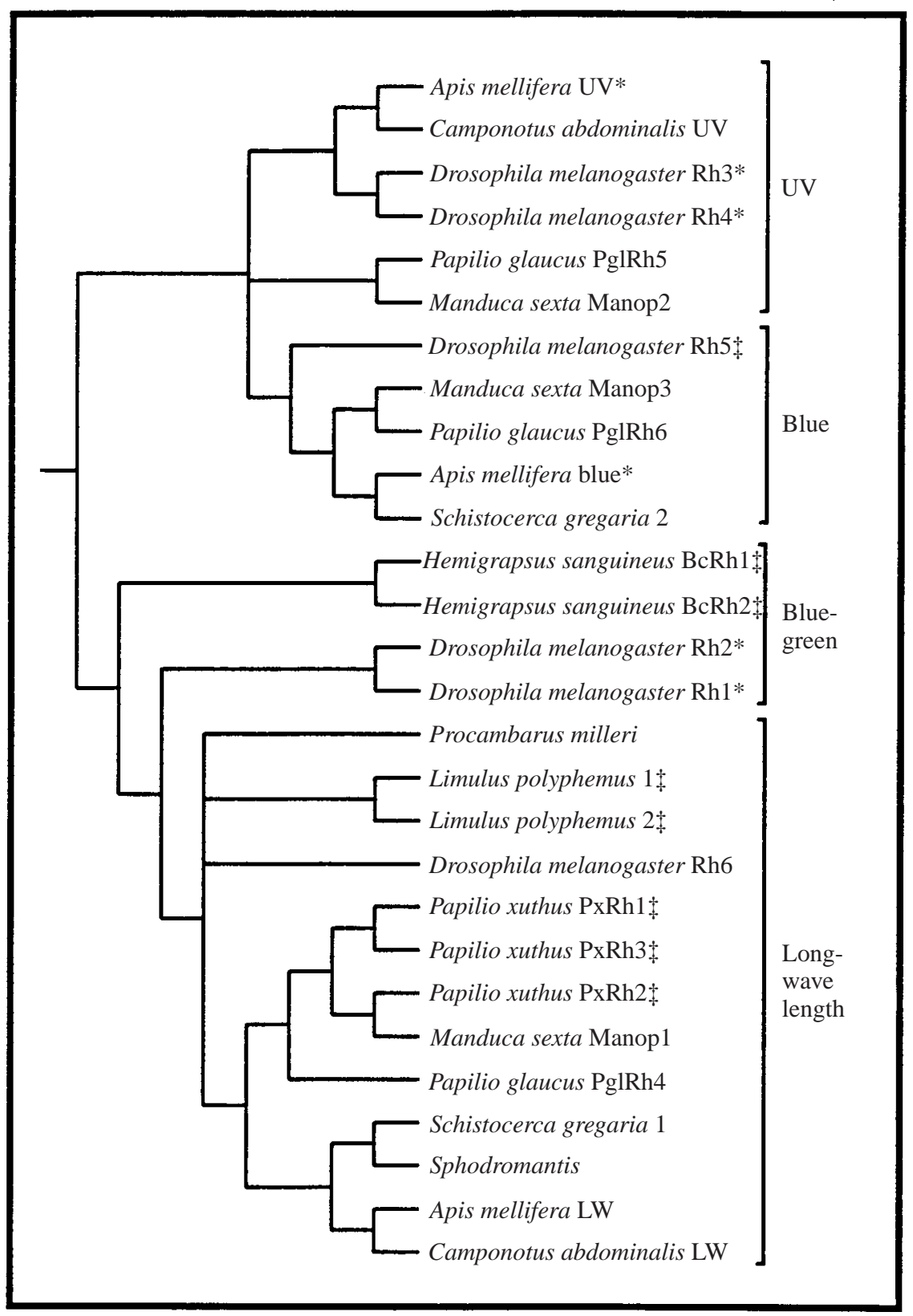

Fig. 2. Phylogeny of insect, chelicerate and crustacean opsins based upon a maximum parsimony analysis of opsin amino acid sequences. Only representative species from available orders or sub-orders are shown. Brackets indicate measured $(*)$ or inferred $(\ddagger)$ spectral properties of the visual pigments (in bold type) in each clade. Inferred spectral properties are based upon in situ hybridization or immunohistochemistry in combination with electrophysiological studies. (The figure is reprinted from Chittka and Briscoe, 2001, with permission from Springer Verlag. The data are taken from several studies cited in the paper.) 


\section{P. G. KEVAN AND OTHERS}

other spectral classes of insect photoreceptors (Cronin et al., 2000). Phylogenetic analyses similar to those we cite remain to be performed for most vertebrates to determine whether or not ultraviolet sensitivity (or its loss) can be considered a special adaptation, and whether spectral fine-tuning can be linked to ecology (see Backhaus et al., 1998). If such analyses indicate the antiquity of ultraviolet vision in vertebrates also, the special question about ultraviolet vision may be 'why has it apparently been lost in some vertebrates?'. Perhaps those in which it has been lost, such as the lineage that includes Homo sapiens, are exceptional.

\section{Ecology and ethology}

Colour vision is probably an ancient phenomenon that arose early in the phylogenies of the Arthropoda and Chordata. Variations in the mechanisms of colour vision can be thought of as refinements of the original Bauplan that included sensitivity in ultraviolet. To illustrate the way in which colour vision and the colours of objects should be considered together, Alfred Russell Wallace's words are worth quoting, bearing in mind that his allusion to the terrestrial world is easily expanded to the marine and aquatic worlds.

"The primary necessity which led to the development of the sense of colour was probably the need of distinguishing objects much alike in form and size, but differing in important properties, such as ripe and unripe, or eatable and poisonous fruits, flowers with honey [=nectar] or without, the sexes of the same or closely allied species. In most cases the strongest contrast would be the most useful, especially as the colours of objects to be distinguished would form but minute spots or points when compared with the broad masses of tint of sky, earth, or foliage against which they would be set." (Wallace 1878, p. 243).

Wallace brings into focus the importance of colour contrast. Studies with honeybees have shown that the detectability of a stimulus (a training target or a flower) depends on the reflections of the background against which neural colorimetric comparisons are made (Backhaus, 1993; Giurfa et al., 1996). The sensitivity of bees, bats and birds to ultraviolet radiation exceeds that in other spectral ranges (von Helversen, 1972; Burkhardt and Maier, 1989; Goldsmith, 1994; Maier, 1992; Winter and von Helversen, 2001). At least in bees, this is simply a consequence of the physiological photoreceptor adaptation process: because daylight is relatively weak in the ultraviolet (and many natural subtrates reflect ultraviolet light poorly), short-wave receptors upregulate their sensitivity (Kevan, 1978; Burkhardt and Maier, 1989) to increase photon capture (Chittka, 1997). Relatively high ultraviolet sensitivity has led some scientists to assume that ultraviolet signals might be highly detectable for some animals. For example, Lutz (Lutz, 1924) suggested that flowers with ultraviolet reflectance should be more readily detectable than other flowers, but lamented that he knew "of no measure of the readiness with which they [the flowers] were found". Since then, many authors have assumed that ultraviolet-reflecting flowers should be particularly easy for insects to find, but no one has quantified detectability, even though colorimetric differences between flowers have been presented in appropriately designed colour spaces (Daumer, 1958; Kevan, 1972; Kevan, 1983; Chittka et al., 1994; Kevan and Backhaus, 1998). Recently developed quantitative measures can be used to determine how readily bees detect flowers of different colours. The results from their application indicate a complex picture: whether ultraviolet reflectance increases or decreases the detectability of an object for a bee depends on the reflectance in other parts of the spectrum.

One way to measure the detectability of a target is to let bees fly into a Y-shaped maze, one of whose arms contains the target and the other does not. One can then determine the probability of choosing the correct arm, depending on the spectral qualities and size of the stimulus. Using this method it was found that in honeybees, detectability of targets from a distance is independent of ultraviolet-specific contrast between target and background (Giurfa et al., 1996). Rather, bees seem to require colour contrast (using input from all three bee receptor types) to find the target. The relative stimulation of the green receptor (target versus background) facilitates detectability, but if colour contrast is absent, bees have difficulty detecting the target at all, even if green contrast is present. Thus, if adding ultraviolet to a given reflectance spectrum diminishes the colour contrast of that target to the background, ultraviolet could actually impair detectability.

The effect of ultraviolet in diminishing the detectability of targets was recently demonstrated using white targets with and without ultraviolet reflectance (Spaethe et al., 2001). To quantify the readiness with which differently coloured targets are detected, the search time taken by bees to find the flowers situated at variable locations within a flight arena was determined. White targets with ultraviolet reflectance in front of a green, foliage-type background yield a strong brightness contrast as well as a strong green contrast. Nevertheless, search times for such flowers were approximately twice as long as those for the white model flowers without ultraviolet reflectance. Daumer (Daumer, 1956) also noted that honeybees did not respond quickly to bee-white stimuli, and Engländer (Engländer, 1941) found that training honeybees to detect white against an ultraviolet target was very difficult. The reason is that, for bees, bee-white-reflecting flowers make poor colour contrast with a green foliage-type background, and that bees ignore brightness differences in the detection and identification of targets (Backhaus, 1992; Kevan et al., 1996), unless the targets are small (Spaethe et al., 2001).

\section{Colour constancy}

If insects are to identify flowers reliably in a natural foraging environment, they need a mechanism to discount changes in illumination colour. Colour constancy is the ability of a visual system to identify a stimulus by its colour, irrespective of the spectral distribution of the illuminant (Hurvich, 1981). In the case of a foraging insect, changes in illumination colour may 
occur regularly as it attempts to locate flowers in patches of sunlight and shade (Dyer, 1998). Behavioural experiments have demonstrated colour constancy in the honeybee (Mazokhin-Porshnyakov, 1966; Neumeyer, 1981; Werner et al., 1988). However, the results of Neumeyer (Neumeyer, 1981) show that bees make more errors in correctly choosing a coloured stimulus when the magnitude of the change in illumination colour is increased. This suggests that bees have imperfect colour constancy (Dyer, 1998), as is known in humans (Hurvich, 1981). The problem of spectrally variable illumination is of particular interest in the case of individual insects that forage temporarily on one flower type, a phenomenon known as flower constancy (Waser, 1986) and appreciated since the time of Aristotle. Flower constancy is potentially of benefit to plants because it confers speciesspecific delivery of pollen, and colour is an important cue in this choice behaviour by insects (Waser, 1986; Chittka et al., 1997; Chittka et al., 1999). Chittka et al. (Chittka et al., 1997) showed that bumblebees sometimes confuse flowers that are of a different species, but have a similar colour signal, thus causing a breakdown in flower constancy. If changes in the spectral distribution of illumination caused insects to mistake more often the colour signal of flowers of one species with those of others, then there would be implications for the reproductive success of the plants.

How is colour constancy implemented on a mechanistic level? One possible mechanism of colour constancy is chromatic adaptation, where the spectral sensitivity of different photoreceptor classes is invariable, but the relative sensitivity of photoreceptors vary to achieve constancy following the von Kries coefficient law (Hurvich, 1981). Theoretical analyses of von Kries colour constancy show that the ability of a visual system to correct for changes in illumination colour may be limited by the spectral breadth and overlap of different photoreceptor classes (Worthey and Brill, 1986; Dyer, 1999a). In the honeybee, the absorption spectra of the blue and green photoreceptors overlap extensively with that of the ultraviolet photoreceptor. This is explained by the secondary $\beta$-peak of the visual pigments (Fig. 1), which is caused by the absorption of short-wavelength radiation by the cis-band of the chromophore. Dyer (Dyer, 1999a) demonstrated that this increased spectral overlap of photoreceptors limits von Kriestype colour constancy for the honeybee, especially for pure ultraviolet colours. Fig. 3 shows the predicted colour shift of loci in a hexagon colour space for a trichromatic insect with ultraviolet, blue and green photoreceptors (based on photoreceptors maximally sensitive at 350, 440 and $540 \mathrm{~nm}$ ) when considering spectrally variable illumination and von Kries colour constancy (Dyer, 1999b). The contours are derived from 99 theoretical stimuli that provide a good coverage of bee colour space (Dyer, 1998) and the colour shift of their loci for illumination varying from a correlated colour temperature of 4800-10000 K (considering von Kries colour constancy). The predicted colour shift is small in the centre right-hand side of colour space, but is larger for pure ultraviolet-coloured flowers lying on the left-hand side of colour space. Indeed, these flowers are rare in nature (Chittka et al., 1994; see Fig. 4), although it is also possible that their scarcity can also be attributed to phylogenetic or biochemical constraints (Chittka, 1997).

Poorer colour constancy for pure-ultraviolet colours, as is predicted for the honeybee, may also be a problem for other animals with ultraviolet photoreceptors, because of the spectral overlap of the ultraviolet photoreceptor with the $\beta$-peaks of the longer wavelength-sensitive receptors. Dyer (Dyer, 1999a; Dyer, 1999b; Dyer, 2001) suggests that a possible function of screening pigments and ocular filters present in the eyes of some species may be to help reduce the effect of the $\beta$-peak on colour constancy.

The possibility of variations in atmospheric $\mathrm{O}_{3}$ concentration affecting the distribution of ultraviolet radiation available as illumination for insects has been suggested (Utech and Kawano, 1975; Meyer-Rochow and Järvilehto, 1997). Ozone in the stratosphere is chiefly responsible for the attenuation of short-wavelength solar radiation reaching the Earth's surface (Kondratyev, 1969). Ozone concentration is naturally variable with both season and latitude, and may also be affected by the release into the atmosphere of carbon

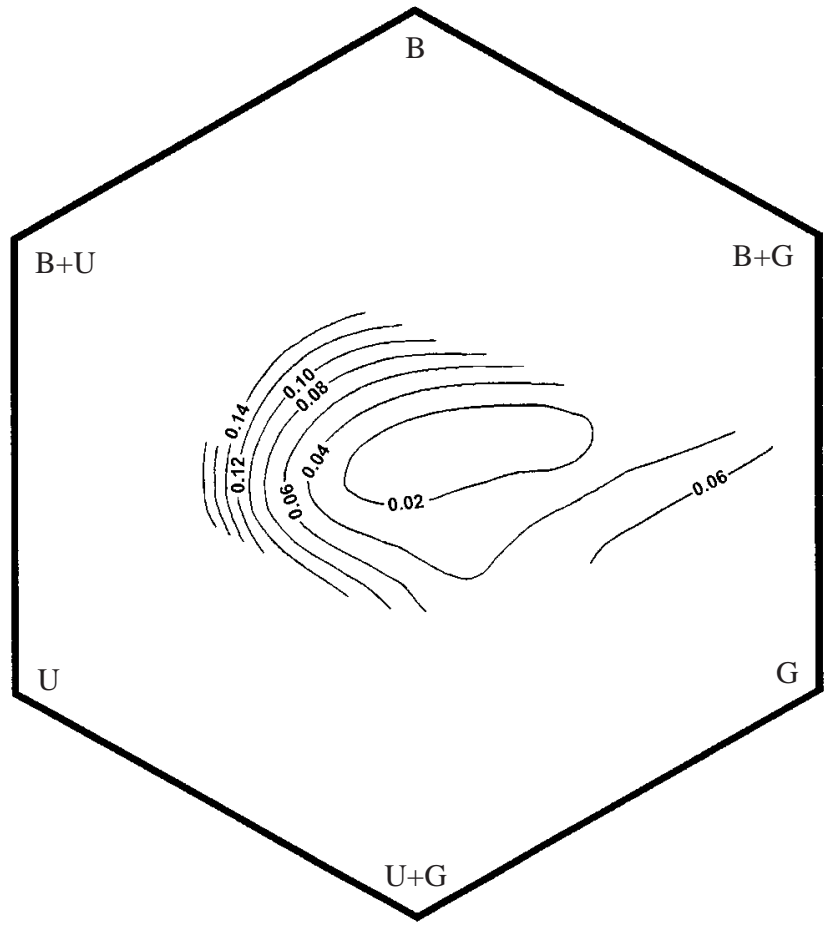

Fig. 3. Hexagon colour space showing contour plots of predicted colour shift, considering von Kries colour constancy and a change in the spectral quality of illumination from a correlated colour temperature of 4800 to $10000 \mathrm{~K}$. Numbers on the contours represent the distance a colour in that region of the hexagon would shift for the change in illumination colour. The distance from the centre of the hexagon to each corner is 1 unit. Colour classes are related to the three photoreceptor peaks (Ultraviolet, Blue and Green) of the honeybee. The contours are calculated from 99 theoretical colours described by Dyer (Dyer, 1998) and are plotted in a hexagon colour space after Chittka (Chittka, 1992). 


\section{P. G. KEVAN AND OTHERS}

dioxide, chlorofluorocarbons, methane and nitrogen oxides (Molina and Rowland, 1974; Alyea et al., 1975; Bruce, 1986; Bowman, 1988). Concerns over the biological damage that can be caused by high-energy, short-wavelength radiation have led to widespread public awareness of $\mathrm{O}_{3}$ depletion and increased ultraviolet radiation levels (Bowman, 1988; Diffey, 1991). The potential effects of variations in atmospheric $\mathrm{O}_{3}$ concentration on colour vision in insects were evaluated with computational models (Dyer, 1999c). The results showed that even a very large variation in $\mathrm{O}_{3}$ concentration would have only a negligible effect on colour vision. This is because, within the range of visual pigments, variations in $\mathrm{O}_{3}$ concentration mainly affect $300-320 \mathrm{~nm}$ radiation, and photoreceptor sensitivity to these wavelengths is relatively low (Fig. 1). Also, the relative amount of $300-320 \mathrm{~nm}$ radiation in natural daylight is very small compared with the rest of the visible spectrum (Henderson, 1977) and, hence, variations in illumination levels at these wavelengths have only a very small influence on the relative stimulation of photoreceptors. However, the findings of Dyer (Dyer, 1999c) do not exclude the possibility of increases in $300-320 \mathrm{~nm}$ radiation affecting wavelengthspecific behavioural mechanisms in some animals. For example, the regulation of circadian physiology in some mammals appears to be controlled by ultraviolet radiation (Brainard et al., 1994). The ultraviolet photoreceptor is sensitive to polarised radiation in some arthropods, fish and

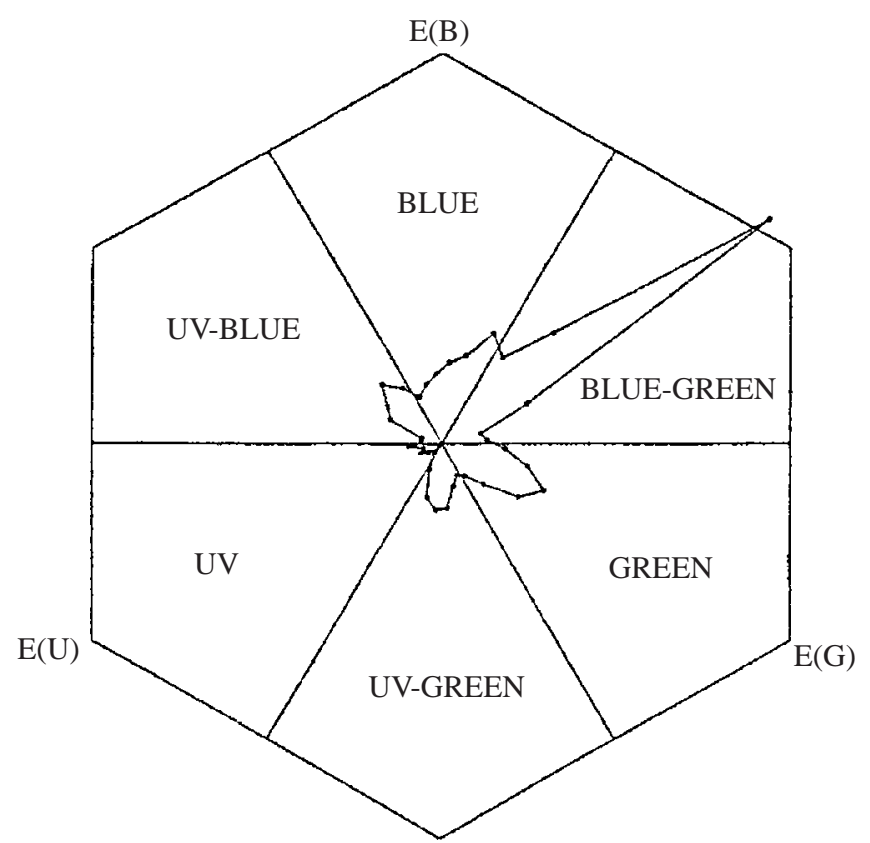

Fig. 4. Hexagon colour space showing the excitations (E) of photoreceptors and the different colour classes for the honeybee. The relative number of flowers occurring in each hue category is plotted in the centre of the hexagon. Hue, in colour space, corresponds to angle, as measured from the centre. Therefore we counted the number of floral colour loci in narrow hue sectors each $10^{\circ}$ wide, with the highest frequency normalised to 1.0 (for details, see Chittka et al., 1994). Blue-green flowers are most common, pure ultraviolet flowers are rare. amphibians (Wehner, 1984), and the phototactic escape responses in some insects shows a maximum sensitivity in the ultraviolet (Wehner, 1981). Recently Mazza et al. (Mazza et al., 1999) have reported that thrips (Caliothrips phaseoli) were able to perceive changes in the relative quantity of 290-320 nm radiation, although they suggest that the mechanism for this detection may be through receptors other than visual ones.

\section{Innate responses to specific colours}

The innate preferences of flower-visiting animals have been much debated. The idea that hummingbirds have an innate preference for red (Raven, 1972; Sutherland and Vickery, 1993) has been largely disproved (Stiles, 1976; Goldsmith and Goldsmith, 1979; Chittka and Waser, 1997), the prevalence of their visits to red flowers not withstanding. Similar associations of floral colours with other flower visitors have been suggested, and the following generalizations have been made (Kevan, 1983): yellow flowers tend to be visited by a wide variety of unspecialized insects, including Diptera and less advanced butterflies; white flowers are also visited by a wide variety of unspecialized insects, including Hymenoptera and Parasitica; blue-reflecting flowers seem to attract the attentions of bees; and pinkish flowers are often associated with visits from butterflies. It has also been suggested that many nocturnally blooming flowers are pale and visited by moths and bats (Winter and von Helversen, 2001). This strict interpretation of floral syndromes in pollination biology has recently received much criticism, and in one habitat near Berlin, we found no statistically significant association between floral colour and pollinator type (Waser et al., 1996). Moreover, even if they exist, none of these associations allows conclusion about innate preference to be drawn (Lunau and Maier, 1995). Some flower visitors have innate colour preferences (Lunau and Maier, 1995; Chittka et al., 2001), but these are easily overcome by learning. Innate attraction to ultraviolet reflections has only rarely been considered and would probably have no importance beyond that of reflections in other wavebands (see below).

Even though honeybees can be trained to distinguish between targets that are equally reflective at blue and green wavelengths and differ only in ultraviolet reflection, or to targets that reflect only ultraviolet radiation, their capacity to do so does not fall outside colour vision and colour opponency coding. It is expected that other animals that can be trained to recognise colours will also process ultraviolet wavelengths as they would any other primary-coloured signal. The importance of ultraviolet reflections is known for floral recognition by insects, even in the few flowers that are pure ultravioletcoloured for bees (e.g. Papaver spp.). It is worth referring to the observation of Lutz (Lutz, 1924) who wrote as follows: "After finding that there are numerous ultraviolet flowers and that flower-visiting insects are keenly sensitive to ultraviolet, I supposed that it would follow, 'as the night the day' that ultraviolet flowers would be... more abundantly visited than those which reflected only ordinary colors... but certainly they are not... more abundantly visited." Lutz (Lutz, 1924) referred 
to ultraviolet reflections as apparently non-adaptive, but in doing so, he failed to recognise that it was ultraviolet in combination with other reflections from flowers that elicited flower-visiting behaviour.

The absence of ultraviolet reflection from almost all white flowers (as they appear to human beings) perhaps has more special meaning because if flowers reflected ultraviolet, blue and green radiations in similar proportions they would occupy much the same colour locus in colour space for trichromatic insects as vegetation. This means that these flowers would be difficult to detect because brightness is not coded by bees (Kevan et al., 1996). The rarity of pure ultraviolet-reflecting flowers might also be partially explained by limitations of colour constancy in insects, as explained above. Indeed, pure ultraviolet-reflecting flowers are very rare in nature, and those that are ultraviolet-reflective in the insect trichromatic colour space appear red to humans. They represent only $1.6 \%$ of 1063 flower reflection spectra measured by Chittka et al. (Chittka et al., 1994; Fig. 4).

Ultraviolet reflections are also important in mate recognition in butterflies (Lepidoptera; Knüttel and Fiedler, 2001), dragonflies and other insects (Silberglied, 1979). In vertebrates, for example birds, ultraviolet reflections are important in mate recognition (Bennett et al., 2001) and food detection (Church et al., 2001), but not outside the purview of colour vision in general. In stomatopod shrimps, it has been suggested that ultraviolet sensitivity might be involved in the detection of objects swimming overhead because of contrast with the bright, ultraviolet-rich skylight (Cronin et al., 1994). Similarly, ultraviolet-bright patches have been invoked as representing escape routes for insects (Menzel, 1979), but other wavebands may also be involved (Kevan, 1979b). Ultraviolet photoreceptors in some insects are used to analyse polarised light, but this task is performed by either blue or green receptors in other insects (Labhart and Meyer, 1999).

In the blue waveband there are only a few examples of special functions. Training experiments with naïve honeybees show that blue targets are learned faster than targets of other colours, such as ultraviolet or green, but less rapidly than targets that stimulate both ultraviolet and blue receptors (Menzel, 1967; Menzel, 1985; Giurfa et al., 1995). Blue light appears to be of primary importance in detection of polarised light in some Orthoptera (Labhart and Meyer, 1999). For some butterflies (Papilio spp. and Pieris brassicae), it has been suggested that blue reflections are important in eliciting feeding activity (Ilse, 1928; Ilse and Vaidya, 1956; Scherer and Kolb, 1987a).

The reflection of green radiation and the green receptor is known to be extremely important in the vision of insects, especially for honeybees. It is important in the detection of motion and in the recognition of size, shape and form (Dafni et al., 1997; Lehrer, 1997). Coloured targets of equal size that combine colour contrast with contrast in the green part of the spectrum (with respect to their backgrounds) are visible to honeybees from approximately three times the distance as coloured targets that lack green contrast (Giurfa et al., 1996).
It has been suggested that green reflections stimulate butterflies to oviposit (Kolb and Scherer, 1982; Scherer and Kolb, 1987b). Green light has also been suggested as important in the detection of polarised light by some beetles (Coleoptera) (Labhart and Meyer, 1999).

Naïve hoverflies (Eristalis tenax Diptera: Syrphidae) land only on human-yellow targets (Ilse, 1949; Lunau, 1988) although they can be trained to choose other coloured targets (Kugler, 1950). Even so, proboscis extension for feeding is elicited only by stimulation between 520 and $600 \mathrm{~nm}$, corresponding to the spectral reflection of pollen (Lunau and Wacht, 1994). Lunau and Maier (Lunau and Maier, 1995) discuss these phenomena on the basis of what is known about the physiology of colour vision in Diptera.

Red reflections have received special attention because some physiologists and ecologists have asserted that bees, and even insects in general, are red-blind (see references in Chittka and Waser, 1997). However, not only are there multiple insect species with specialised red receptors (Bernard, 1979; Peitsch et al., 1992, Briscoe and Chittka, 2001), but red flowers are not invisible to insects that lack a specific red receptor, and trichromatic insects including the honeybee do visit red flowers (Chittka and Waser, 1997).

Red stimuli also elicit feeding responses from some butterflies (Gonopteryx rhamni and Pieris brassicae; Kühn and Ilse, 1925; Scherer and Kolb, 1987a). The red bowl-shaped flowers of the Mediterranean are pollinated extensively by Amphicoma beetles (Dafni et al., 1990), and these animals possess red receptors (Briscoe and Chittka, 2001).

The meaning of black objects (achromatic stimuli of very low reflectance throughout the entire spectrum) is less clear and has rarely been examined with respect to insect or bird colour vision. Certain flowers have black patterns within their corollas (e.g. Iris spp.), and presumably these patterns provide information to flower visitors when perceived in relation to the rest of the corollas' reflectance spectra. Black flowers are almost unknown in nature. One possible exception is the putatively hummingbird-pollinated Lisianthus spp. of southern Mexico (Markham et al., 2001). Fruits that appear black to humans are common, although some of these fruits reflect ultraviolet (Burkhardt, 1982).

\section{Biogeography and floral forms}

The biogeography of flower colours has been debated and it is suggested that they might relate to environmental conditions, genetic drift and the nature of pollinator assemblages, past or present (Chittka et al., 2001). Such considerations have often been made without reference to pollinator colour vision (see Kevan, 1983). Now that there are several floras to assess, it seems that floras with especially low incidences of ultravioletreflecting flowers are those in which Hymenoptera are not the dominant pollinators (e.g. the Arctic and in alpine ultravioletrich environments and in Hawaii; Table 1). This situation may reflect the nature of the pollinator assemblages and the floras of these regions. It is recognised that the incidence of floral 
Table 1. Frequency of ultraviolet reflecting flowers in the floras of different geographic regions

\begin{tabular}{lccc}
\hline Location & $\begin{array}{c}\text { Number of } \\
\text { species }\end{array}$ & $\begin{array}{c}\text { Frequency of } \\
\text { flowers reflecting } \\
\text { ultraviolet (\%) }\end{array}$ & Reference \\
\hline USA (Colorado and New Jersey) & 100 & 30 & Lutz, 1924 \\
Europe & 80 & 25 & Motmar, 1933 \\
Russia (Moscow) & 80 & 33 & Guldberg and Atsatt, 1975 \\
USA (California) & 300 & 33 & Chittka et al., 1994 \\
Various & 573 & 25.7 & Dyer, 1996 \\
Australia (Victoria) & 86 & 24.4 & Kevan, 1972 \\
Canada (Arctic) & 73 & $14^{*}$ & Inouye and Pyke, 1988 \\
Australia (Snowy Mountains) & 38 & $16^{*}$ & Jones et al., 1999 \\
Hawaii & 104 & $13.5 *$ & Mulligan and Kevan, 1973
\end{tabular}

*Where bees are not the major pollinators (in the Arctic, in mountain regions and in Hawaii), the incidence of ultraviolet-reflecting flowers is statistically significantly lower than the overall frequency $\left(P=0.02, \chi^{2}\right.$-test $)$.

nectar-guides (patterns of coloration that can be used by flower visitors to orient themselves on flowers to find rewards), including those that comprise ultraviolet reflections, vary with pollinator type and floral form. Kugler (Kugler, 1963) noted that, for flowers pollinated primarily by butterflies, $83 \%$ have nectar guides reflecting in approximately equal proportions in the ultraviolet $(66 \%)$ or human-visible $(63 \%)$ range. He noted that $67 \%$ of zygomorphic (bilaterally symmetrical) flowers have nectar-guides, but they predominate in the human-visible part of the spectrum ( $68 \%$ versus $48 \%$ in the ultraviolet). In contrast he noted that, in capitulate inflorescences, such as those of sunflowers and daisies, nectar-guides were less frequent $(67 \%)$, with ultraviolet reflections predominating $(56 \%)$ over human-visible reflections $(30 \%)$. Simpler flowers are less likely to have nectar guides (approximately 50\%) with a slight tendency to favour ultraviolet over human-visible reflection. Guldberg and Atsatt (Guldberg and Atsatt, 1975) make some similar generalisations, noting that small flowers $(<1 \mathrm{~cm}$ in diameter) are much less likely to have ultravioletreflecting patterns $(15 \%)$ than are large flowers $(>7.5 \mathrm{~cm}$ in diameter, $70 \%$ ). It is again difficult to attribute any special function to ultraviolet coloration of flowers from either biogeographic or morphological viewpoints, apart from the general importance of colour (Kevan, 1983).

\section{Concluding remarks}

We conclude that there is little evidence to suggest that ultraviolet is a special waveband for the visual systems of animals and its importance has often been exaggerated (Kevan, 1972; Kevan, 1978; Kevan, 1979a; Kevan, 1983; Chittka et al., 1994; Lunau, 1992; Kevan and Backhaus, 1998). Ultraviolet is merely one component of visual stimuli that might be of interest to animals (flowers, fruits, mates, enemies, escape routes, oviposition substrates, etc.). Although certain wavebands of light do sometimes have special significance to some animals, ultraviolet wavelengths do not appear to be any more significant than other wavelengths. These results suggest that caution is required in interpreting the significance of ultraviolet signals in the absence of information from other regions of an animal's visible spectrum. For the meaningful evaluation of most animal behaviours, and especially where colour vision is concerned, we argue that the salience of ultraviolet signals is indeed limited. Investigators interested in how animals visualise objects in their environments, and how those objects might appear to animals, must exercise caution and place ultraviolet radiation into its appropriate contexts.

We are grateful to Dr L. L. Muir and Professor W. R. A. Muntz for their comments on the manuscript. L. Chittka was supported by the Deutsche Forschungsgemeinschaft (grants SFB554 and Ch 147/3-1).

\section{References}

Alyea, F. N., Cunnold, D. M. and Prinn, R. G. (1975). Stratospheric ozone destruction by aircraft-induced nitrogen oxides. Science 188, 117-121.

Arikawa, K., Inokuma, K. and Eguchi, E. (1987). Pentachromatic visual system in a butterfly. Naturwissenschaften 74, 297-298.

Backhaus, W. (1991). Color opponent coding in the visual system of the bee. Vision Res. 31, 1381-1397.

Backhaus, W. (1992). The Bezold-Brücke effect in the color vision system of the honeybee. Vision Res. 32, 1425-1431.

Backhaus, W. (1993). Color vision and color choice behavior of the honey bee. Apidologie 24, 309-331.

Backhaus, W. G. K., Kliegl, R. and Werner, J. S. (1998) (ed.). Color Vision: Perspectives from Different Disciplines. Berlin, Germany: De Gruyter.

Bennett, A. T. D. and Cuthill, I. C. (1994). Ultraviolet vision in birds: What is its function? Vision Res. 34, 1471-1478.

Bennett, A. T. D., Cuthill, I. C., Partridge, J. C. and Maier, E. J. (1996). Ultraviolet vision and mate choice in zebra finches. Nature 380, 433-435.

Bennett, A. T. D., Hunt, S., Cuthill, I. C. and Partridge, J. C. (2001). UV vision and mate choice in estrildid finches from Africa, Asia, and Australia. J. Exp. Biol. 204, 000-000.

Berkner, L. V. and Marshall, L. C. (1965). On the origin and rise of oxygen concentration in the Earth's atmosphere. J. Atmosph. Sci. 22, 225-261.

Bernard, G. D. (1979). Red-absorbing visual pigment of butterflies. Science 203, 1125-1127.

Bowmaker, J. K. (1980). Birds see ultraviolet light. Nature 284, 306

Bowman, K. P. (1988). Global trends in total ozone. Science 239, 48-50.

Brainard, G. C., Barker, F. M., Hoffman, R. J., Stetson, M. H., Hanifin, J. P., Podolin, P. L. and Rollag, M. D. (1994). Ultraviolet regulation of 
neuroendocrine and circadian physiology in rodents. Vision Res. 34 1521-1533.

Briscoe, A. and Chittka, L. (2001). The evolution of color vision in insects. Annu. Rev. Ent. 46, 471-510.

Bruce, J. P. (1986). Man's impact on Earth's atmosphere. In Effects of Changes in Stratospheric Ozone and Global Climate, vol. 1 (ed. J. G. Titus), pp. 35-51. Washington, DC: US Environmental Protection Agency/United Nations Environment Programme.

Burkhardt, D. (1982). Birds, berries, and UV: a note on some consequences of UV vision in birds. Naturwissenschaften 69, 153-157.

Burkhardt, D. and Maier, E. (1989). The spectral sensitivity of a passerine bird is highest in the UV. Naturwissenschaften 76, 82-83.

Chittka, L. (1992). The colour hexagon: A chromaticity diagram based on excitations as a generalized representation of colour opponency. J. Comp. Physiol. A 170, 533-543.

Chittka, L. (1996). Does bee color vision predate the evolution of flower color? Naturwissenschaften $\mathbf{8 3}, 136-138$.

Chittka, L. (1997). Bee color vision is optimal for coding flower color, but flower colors are not optimal for being coded. Isr. J. Plant Sci. 45, 115-128.

Chittka, L. and Briscoe, A. (2001). Why sensory ecology needs to become more evolutionary - insect color vision as a case in point. In The Ecology of Sensing (ed. F. G. Barth and A. Schmid), pp. 19-38. Berlin: Springer Verlag.

Chittka, L. and Dornhaus, A. (1999). Comparisons in physiology and evolution, and why bees can do the things they do. Ciencia al Dia 2, $1-17$.

Chittka, L., Spaethe, J., Schmidt, A. and Hickelsberger, A. (2001). Adaptation, constraint, and chance in the evolution of flower color and pollinator color vision. In Cognitive Ecology of Pollination (ed. L. Chittka and J. D. Thomson), pp. 106-126. Cambridge: University Press.

Chittka, L. and Menzel, R. (1992). The evolutionary adaptation of flower colors and the insect pollinators' color vision systems. J. Comp. Physiol. A 171, 171-181.

Chittka, L., Shmida, A., Troje, N. and Menzel, R. (1994). Ultraviolet as a component of flower reflections, and the colour perception of Hymenoptera. Vision Res. 34, 1489-1508

Chittka, L., Gumbert, A. and Kunze, J. (1997). Foraging dynamics of bumble bees: correlates of movements within and between plant species. Behav. Ecol. 8, 239-249.

Chittka, L., Thomson, J. D. and Waser, N. M. (1999). Flower constancy, insect psychology, and plant evolution. Naturwissenschaften 86, 361-377.

Chittka, L. and Waser, N. M. (1997). Why red flowers are not invisible to bees. Isr. J. Plant Sci. 45, 169-184.

Church, S. C., Maddocks, S. A., Cuthill, I. C. and Partridge, J. C. (2001). Avian UV vision and seed preferences. J. Exp. Biol. 204, 000-000.

Cronin, T. W., Järvilehto, M., Weckström, M. and Lall, A. B. (2000). Tuning of photoreceptor spectral sensitivity in fireflies (Coleoptera: Lampyridae). J. Comp. Physiol. A 186, 1-12.

Cronin, T. W. and Marshall, N. J. (1989). Multiple spectral classes of photoreceptors in the retinas of gonodactyloid stomatopod crustaceans. $J$. Comp. Physiol. A 106, 267-275.

Cronin, T. W., Marshall N. J., Quinn C. A. and King C. A. (1994). Ultraviolet perception in mantis shrimp. Vision Res. 34, 1443-1449.

Dafni, A., Bernhardt, P., Shmida, A., Ivri, Y., Greenbaum, S., O'Toole, C. and Losito, L. (1990). Red bowl-shaped flowers: Convergence for beetle pollination in the Mediterranean. Isr. J. Bot. 39, 81-92.

Dafni, A., Lehrer, M. and Kevan, P. G. (1997). Spatial flower parameters and insect spatail vision. Biol. Rev. 72, $239-282$.

Daumer, K. (1956). Reizmetrische Untersuchungen des Farbensehens der Bienen. Z. Vergl. Physiol. 38, 413-478.

Daumer, K. (1958). Blumenfarben: wie sie der Bienen sehen. Z. Vergl. Physiol. 41, 49-110.

Diffey, B. L. (1991). Solar ultraviolet radiation effects on biological systems. Phys. Med. Biol. 36, 299-328.

Dyer, A. G. (1996). Reflection of near-ultraviolet radiation from flowers of Australian native plants. Aust. J. Bot. 44, 473-488.

Dyer, A. G. (1998). The colour of flowers in spectrally variable illumination and insect pollinator vision. J. Comp. Physiol. A 183, 203-212.

Dyer, A. G. (1999a). Broad spectral sensitivities in the honeybee's photoreceptors limit colour constancy. J. Comp. Physiol. A 185, 445-453.

Dyer, A. G. (1999b). The colour of flowers in spectrally variable illumination and insect pollinator vision. PhD Thesis, RMIT University, Melbourne, Australia.
Dyer, A. G. (1999c). Atmospheric ozone concentration and the colour vision of insect pollinators. Aust. J. Zool. 47, 529-538.

Dyer, A. G. (2001). Ocular filtering of ultraviolet radiation and the spectral spacing of photoreceptors benefit von Kries colour constancy. J. Exp. Biol. 204, 2391-2399.

Engländer, H. (1941). Die Bedeutung der weißen Farbe für die Orientierung der Bienen am Stand. Arch. Bienenkunde 22, 516-549.

Garrels, R. M., Lerman, A. and Mackenzie, F. T. (1976). Controls of atmospheric $\mathrm{O}_{2}$ and $\mathrm{CO}_{2}$ : Past, present, and future. Am. Sci. 64, 306-315.

Giurfa, M., Núñez, J., Chittka, L. and Menzel, R. (1995). Colour preferences of flower-naive honeybees. J. Comp. Physiol. A 177, 247-259.

Giurfa, M., Vorobyev, M., Kevan, P. G. and Menzel, R. (1996). Detection of coloured stimuli by honeybees: minimum visual angles and receptor specific contrasts. J. Comp. Physiol. A 178, 699-709.

Goldsmith, T. H. (1980). Hummingbirds see near ultraviolet light. Science 207, 786.

Goldsmith, T. H. (1990). Optimization, constraint, and history in the evolution of eyes. Quart. Rev. Biol. 65, 281-322.

Goldsmith, T. H. (1994). Ultraviolet receptors and color vision: evolutionary implications and a dissonance of paradigms. Vision Res. 34, 1479-1487.

Goldsmith, T. H. and Goldsmith, K. M. (1979). Discrimination of colors by the black-chinned hummingbird, Archilochus alexandri. J. Comp. Physiol. A 130, 209-220.

Guldberg, L. and Atsatt, P. R. (1975). Frequency of reflection and absorption of ultraviolet light in flowering plants. Am. Midl. Nat. 93, 35-43.

von Helverson, O. (1972). Zur spektralen Unterschiedempfindlichkeit der Honigbienen. J. Comp. Physiol. A 80, 439-472.

Henderson, S. N. (1977). Daylight and its Spectrum, second edition. New York: John Wiley \& Sons.

Hurvich, L. M. (1981). Color Vision. Sunderland, MA: Sinauer Associates Inc.

Ilse, D. (1928). Über den Farbensinn der Tagfalter. Z. Vergl. Physiol. 8, 658-692.

Ilse, D. (1949). Colour discrimination in the dronefly, Eristalis tenax. Nature 163, 255-256.

Ilse, D. and Vaidya, V. G. (1956). Spontaneous feeding response to colours in Papilio demoleus L. Proc. Indian Acad. Sci. B 43, 23-31.

Inouye, D. and Pyke, G. H. (1988). Pollination biology in the Snowy Mountains of Australia: comparisons with montane Colorado, USA. Aust. J. Ecol. 13, 191-210.

Jacobs, G. H. (1992). Ultraviolet vision in vertebrates. Am. Zool. 32, 544-554.

Jones, C. E., Dorsett, D. K., Roelofs, F. M. and Shah, C. V. (1999). Ultraviolet floral patterns in the native Hawaiian flora: What do they mean for island biogeography? Pacific Sci. 53, 82-87.

Kevan, P. G. (1972). Floral colours in the High Arctic with reference to insect flower relations and pollination. Can. J. Bot. 50, 2289-2316.

Kevan, P. G. (1978). Floral coloration, its colorimetric analysis and significance in anthecology. In The Pollination of Flowers by Insects (ed. A. J. Richards), pp. 51-78. Linnean Society Symposium No. 6, London: Academic Press.

Kevan, P. G. (1979a). Vegetation and floral colors using ultraviolet light: Interpretational difficulties for functional significance. Am. J. Bot. 66, 749-751.

Kevan, P. G. (1979b). The spectral efficiency of phototaxis in some High Arctic Diptera. J. Arctic Alpine Res. 11, 349-352.

Kevan, P. G. (1983). Floral colors through the insect eye: What they are and what they mean. In Handbook of Experimental Pollination Biology (ed. C. E. Jones and R. J. Little), pp. 3-25. Scientific and Academic Editions. New York: Van Nostrand \& Co.

Kevan, P. G. and Backhaus, W. G. K. (1998). Color vision: Ecology and evolution in making the best of the photic environment. In Color Vision: Perspectives from Different Disciplines (ed. W. G. K. Backhaus, R. Kliegl and J. S. Werner), pp. 163-183. Berlin: De Gruyter.

Kevan, P. G., Giurfa, M. and Chittka, L. (1996). Why are there so many and so few white flowers? Trends Plant Sci. 1, 280-284.

Knuth, P. (1891a). Die Einwirkung der Blütenfarben auf der photographische Platte. Biol. Centralbl. 48, 160-165.

Knuth, P. (1891b). Weytere Beobachtungen uber die Anlockungsmittel der Blüten von Sycos angulata L. and Bryonica dioica L. Biol. Centralbl. 48, 314-318.

Knüittel, H. and Fiedler, K. (2001). Host-plant-derived variation in ultraviolet wing patterns influences mate selection by male butterflies. J. Exp. Biol. 204, 2447-2459.

Kolb, G. and Scherer, C. (1982). Experiments on wavelength specific 
behaviour of Pieris brassicae L. during drumming and egg-laying. J. Comp. Physiol. A 149, 325-332.

Kondratyev, K. Y. A. (1969). Radiation in the Atmosphere. New York: Academic Press.

Kugler, H. (1950). Der Blütenbesuch der Schammfliege (Eristalomyia tenax). Z. Vergl Physiol. 32, 328-347.

Kugler, H. (1963). UV-Musterungen auf Blüten und ihr Zustandekommen. Planta 59, 296-329.

Kühn, A. (1924). Zum Nachweiss des Farbunterscheidungsvermögen der Beinen. Naturwissenschaften 12, 116.

Kühn, A. (1927). Über den Farbensinn der Bienen. Z. Vergl. Physiol. 5, 762-800.

Kühn, A. and Ilse, D. (1925). Die Anlockung von Tagfaltern durch Pigmentfarben. Biologische Zentralblätter 45, 144-149.

Labhart, T. and Meyer, E. P. (1999). Detectors for polarized skylight in insects: a survey of ommatidial specializations in the dorsal rim area of the compound eye. Microsc. Res. Tech. 47, 368-379.

Lehrer, M. (1997). Honeybee's use of spatial parameters for flower discrimination. Isr. J. Plant Sci. 45, 157-168.

Lotmar, R. (1933). Neue Untersuchungen über den Farbensinn der Bienen, mit besonderer Berücksichtigung des Ultravioletts. Z. Vergl Physiol. 19, 673-723.

Lubbock, Sir J. (1881). Observations on ants, bees, and wasps. IX. Color of flowers as an attraction to bees: Experiments and considerations thereon. $J$. Linn. Soc. Lond. (Zool.) 16, 110-112.

Lunau, K. (1988). Innate and learned behaviour of flower-visiting hoverflies - flower-dummy experiments with Eristalis pertinax (Scopoli) (Diptera: Syrphidae). Zool. Jahrbuch Physiol. 92, 487-499.

Lunau, K. (1992). Innate recognition of flowers by bumblebees - orientation of antennae to visual signals. Can. J. Zool. 70, 2139-2144.

Lunau, K. and Maier, E. J. (1995). Innate colour preferences of flower visitors. J. Comp. Physiol. A 177, 1-19.

Lunau, K. and Wacht, S. (1994). Visual key stimuli to the innate proboscis extension in the hoverfly Eristalis tenax L. (Syrphidae: Diptera). J. Comp. Physiol. A 174, 575-579.

Lutz, F. E. (1924). Apparently non-selective characters and combinations of characters, including a study of ultraviolet in relation to the flower-visiting habits of insects. Ann. New York Acad. Sci. 29, 181-283.

McFarland, W. N. and Munz, F. W. (1975). Part III: The evolution of photopic visual pigments in fishes. Vision Res. 15, 1071-1080.

Maier, E. J. (1992). Spectral sensitivities including the ultraviolet of the passeriform bird Leiothrix lutea. J. Comp. Physiol. A 170, 709-714.

Markham, K. R., Bloor, S. J., Nicholson, R., Rivera, P., Shemluk, M. P. and Kevan, P. G. (2001). Black flower colouration in wild Lisianthus nigrescens - its chemistry and ecological consequences. Plant Physiology and Biochemistry (in press).

Mazokhin-Porshnyakov, G. A. (1959). Reflection of ultraviolet rays by flowers and insect vision. Entomol. Rev. 38, 285-296.

Mazokhin-Porshnjakov, G. A. (1966). Recognition of coloured objects by insects. In The Functional Organization of the Compound Eye (ed. C. G. Bernhard), pp. 163-170. Oxford: Pergamon Press.

Mazza, C. A., Zavala, J., Scopel, A. L. and Ballaré, C. L. (1999). Perception of solar UVB radiation by phytophagous insects: behavioural responses and ecosystem implications. Proc. Natl. Acad. Sci. USA 96, 980-985.

Menzel, R. (1967). Untersuchungen zum Erlernen von Spektralfarben durch die Honigbiene (Apis mellifica). Z. Vergl. Physiol. 56, 22-62.

Menzel, R. (1979). Spectral sensitivity and colour vision in invertebrates. In Handbook of Sensory Physiology (ed. H. Autrum), pp. 503-580, Volume VII/6A. Berlin: Springer Verlag.

Menzel, R. (1985). Learning in honey bees in an ecological and behavioral context. In Experimental Behavioral Ecology (ed. B. Hölldobler and M. Lindauer), pp. 55-74, Volume 31. Stuttgart: Gustav Fischer Verlag.

Menzel, R. and Shmida, A. (1993). The ecology of flower colours and the natural colour vision of insect pollinators: The Israeli flora as a study case. Biol. Rev. 68, 81-120.

Meyer-Rochow, V. B. and Järvilehto, M. (1997). Ultraviolet colours in Pieris napi from Northern and Southern Finland: Arctic females are the brightest. Naturwissenschaften $\mathbf{8 4}, 165-168$.

Molina, M. J. and Rowland, F. S. (1974). Stratospheric sink for chlorofluoromethanes: chlorine atom-catalysed destruction of ozone. Nature 249, 810-812.

Morel, A. (1974). Optical properties of pure water and pure sea water. In Optical Aspects of Oceanography (ed. N. G. Jerlov and E. S. Nelson), pp. 1-24. London: Academic Press.

Mulligan, G. A. and Kevan, P. G. (1973). Colour, brightness, and other characteristics attracting insects to the blossoms of some Canadian weeds. Can. J. Bot. 51, 1939-1952.

Neumeyer, C. (1981). Chromatic adaptation in the honey bee: successive color contrast and color constancy. J. Comp. Physiol. A 144, 543-553.

Neumeyer, C. (1985). An ultraviolet receptor as a fourth receptor type in goldfish colour vision. Naturwissenschaften 72, 162-163.

Neumeyer, C. (1991). Evolution of colour vision. In Evolution of the Eye and Visual System (ed. J. R. Cronly-Dillon and R. L. Gregory), pp. 284-298. London: Macmillan Press.

Neumeyer, C. (1992). Tetrachromatic color vision in goldfish: Evidence from colour mixing experiments. J. Comp. Physiol. A 171, 639-649.

Neumeyer, C. (1998). Color vision in lower vertebrates. In Perspectives from Different Disciplines (ed. W. G. K. Backhaus, R. Kliegl and J. S. Werner), pp. 149-162. Berlin: De Gruyter.

Osorio, D. and Bacon, J. P. (1994). A good eye for arthropod evolution. BioEssays 16, 419-424.

Peitsch, D., Fietz, A., Hertel, H., de Souza, J., Ventura, D. F. and Menzel, R. (1992). The spectral input systems of hymenopteran insects and their receptor-based colour vision. J. Comp. Physiol. A 170, 23-40.

Raven, P. H. (1972). Why are bird-visited flowers predominantly red? Evolution 26, 774.

Scherer, C. and Kolb, G. (1987a). Behavioural elements on the visual processing of colour stimuli in Pieris brassicae L (Lepidoptera). J. Comp. Physiol. A 160, 645-656.

Scherer, C. and Kolb, G. (1987b). The influence of colour stimuli on visually controlled behaviour in Aglais urticae L. and Pararge aegeria L.(Lepidoptera). J. Comp. Physiol. A 161, 891-898.

Silberglied, R. E. (1979). Communication in the ultraviolet. Ann. Rev. Ecol. Systematics 10, 373-398.

Spaethe, J., Tautz, J. and Chittka, L. (2001). Visual constraints in foraging bumble bees: flower size and colour affect search time and flight behavior. Proc. Nat. Acad. Sci. (in press).

Stavenga, D. G., Smits, R. P. and Hoenders, B. J. (1993). Simple exponential functions describing the absorbance bands of visual pigment spectra. Vision Res. 33, 1011-1017.

Stiles, G. F. (1976). Taste preferences, color preferences, and flower choice in hummingbirds. The Condor 78, 10-26.

Sutherland, S. D. and Vickery, R. K., Jr. (1993). On the relative importance of floral color, shape, and nectar rewards in attracting pollinators to Mimulus. Great Basin Nat. 53, 107-117.

Tovée, M. J. (1995). Ultra-violet photoreceptors in the animal kingdom: their distribution and function. Trends Ecol. Evol. 11, 455-460.

Utech, F. H. and Kawano, S. (1975). Spectral polymorphisms in angiosperm flowers determined by differential ultraviolet reflectance. Bot. Mag. Tokyo 88, 9-30.

Vorobyev, M. and Brandt, R. (1997). How do insects discriminate colors? Isr. J. Plant Sci. 45, 103-113.

Vorobyev, M., Osorio, D., Bennett, A. T. D., Marshall, N. J. and Cuthill, I. C. (1998). Tetrachromacy, oil droplets and bird plumage colours. $J$. Comp. Physiol. A 183, 621-633.

Wallace, A. R. (1878). Tropical Nature and Other Essays. London: Macmillan and Company. 356pp.

Waser, N. M. (1986). Flower constancy: definition, cause, and measurement. Am. Nat. 127, 593-603.

Waser, N. M., Chittka, L., Price, M. V., Williams, N. and Ollerton, J. (1996). Generalization in pollination systems, and why it matters. Ecology 77, 1043-1060.

Wehner, R. (1981). Spatial vision in arthropods. In Handbook of Sensory Physiology, vol. VII/6c (ed. H. Autrum), pp. 287-616. Berlin: SpringerVerlag.

Wehner, R. (1984). Navigation by polarized skylight. In Comparative Physiology of Sensory Systems (ed. L. Bolis, R. D. Keynes and S. H. P. Maddrell), pp. 497-507. Cambridge: Cambridge University Press.

Werner, A., Menzel, R. and Wehrhahn, C. (1988). Color constancy in the honeybee. J. Neurosci. 8, 156-159.

Winter, Y. and von Helversen, O. (2001). Bats as pollinators: foraging energetics and floral adaptations. In Cognitive Ecology of Pollination (ed. L. Chittka and J. D. Thomson). Cambridge: University Press (in press).

Wolff, H. (1925). Das Farbunterscheidungsvermögen der Elritze. Z. Vergl. Physiol. 3, 279-329.

Worthey, J. A. and Brill, M. H. (1986). Heuristic analysis of von Kries color constancy. J. Opt. Soc. Am. A 3, 1708-1712.

Wyszecki, G. and Stiles, W. S. (1967). Colour Science: Concepts and Methods, Qualitative Data and Formulas. New York: Wiley. 